\title{
PENERAPAN MODEL KOOPERATIF TIPE NUMBERED HEADS TOGETHER (NHT) MENGGUNAKAN MEDIA BUKLET PADA MATERI KLASIFIKASI MAKHLUK HIDUP DI SMP NEGERI 5 BAU-BAU
}

\author{
Wa Ode Hariyana \\ Dinas Pendidikan, Pemuda, dan Olahraga Kota Baubau, SMP Negeri 5 Baubau \\ Jl. Anoa No. 21 B. Baubau. \\ E-mail:waodehariyana@gmail.com
}

\begin{abstract}
Abstrak
Tujuan penelitian ini adalah untuk mengetahui efektivitas penerapan pembelajaran kooperatif tipe NHT menggunakan media buklet pada materi klasifikasi makhluk hidup. Populasi penelitian ini adalah siswa kelas VII semester gasal sebanyak enam kelas, yaitu kelas VII-1, VII-2, VII-3, VII-4, dan VII-5. Sampel dalam penelitian ini adalah dua kelas dari lima kelas yang ada. Hasil penelitian menunjukan bahwa penerapan model kooperatif tipe NHT menggunakan media buklet dapat mengoptimalkan hasil belajar dan aktivitas siswa pada materi klasifikasi makhluk hidup di SMP Negeri 5 Baubau. Sebanyak 100\% siswa merasa pembelajaran kooperatif tipe NHT mempermudah dalam mempelajari materi klasifikasi makhluk hidup.
\end{abstract}

Kata kunci: buklet, hasil belajar, Kooperatif Tipe Numbered Heads Together (NHT).

\begin{abstract}
The purpose of this study is to determine the effectiveness of the application of cooperative learning type NHT using the media booklet on the material classification of living things. The population of this study are sixth grade class of VII semester students, namely class VII-1, VII-2, VII-3, VII-4, and VII-5. The sample in this study is two classes of five existing classes. The results showed that the application of NHT type cooperative model using booklet media can optimize learning outcomes and student activities on the material classification of living things in SMP Negeri 5 Baubau. As many as 100\% of students feel NHT type cooperative learning makes it easier to study the material classification of living things.
\end{abstract}

Keywords: booklet, learning result, Co-operative Numbered Heads Together (NHT) Type. 


\section{SANG PENCERAH}

Volume 3, Nomor 1, Februari 2017, Hlm. 63-73

Wa Ode Hariyana: Penerapan Model Kooperatif Tipe ...

\section{Pendahuluan}

Dalam Dalam proses belajar mengajar pada dasarnya merupakan proses interaksi antara yang belajar (siswa) dengan pengajar (guru). Seorang siswa telah dikatakan belajar apabila ia telah mengetahui sesuatu yang sebelumnya ia tidak ketahui, termasuk sikap tertentu yang sebelumnya belum dimilikinya. Sebaliknya, seorang guru dikatakan telah mengajar apabila ia telah membantu siswa atau orang lain untuk memperoleh perubahan yang dikehendaki.

Guru dituntut melaksanakan kegiatan belajar mengajar semenarik mungkin sehingga siswa senang mengikuti pelajaran. Tapi pada kenyataannya guru hanya menggunakan metode ceramah saja dalam pembelajaran. Pembelajaran dengan metode ceramah masih berpusat pada guru bukan pada siswa, sehingga kurang memberikan kesempatan siswa untuk berinteraksi. Motivasi siswa menjadi kurang dalam pelajaran tersebut sehingga hasil belajar cenderung rendah. Agar kegiatan pembelajaran menjadi menarik perlu variasi metode pembelajaran, selain itu penggunaan media pembelajaran yang bervariasi juga akan meningkatkan motivasi belajar dan hasil belajar siswa.

Berdasarkan observasi di SMP Negeri 5 Baubau pada 25 Februari 2012 dalam pembelajaran klasifikasi makhluk hidup, guru menggunakan metode ceramah diselingi kegiatan diskusi. Pelaksanaan metode pembelajaran ceramah tidak berjalan optimal, karena sewaktu pembelajaran siswa kurang termotivasi mengikuti pelajaran dan siswa ramai sendiri. Ketika melakukan diskusi tidak semua siswa ikut aktif dalam kegiatan tersebut. Ada beberapa siswa yang bermain sendiri, tidak peduli dengan tugasnya dan mereka mengandalkan teman yang lain untuk menyelesaikan tugas tersebut. Berdasarkan data nilai ulangan harian materi klasifikasi makhluk hidup pada semester gasal tahun 2011/2012, rerata hasil belajar siswa kelas VII hanya 67,51 berada dibawah Kriteria Ketuntasan Minimal (KKM). KKM untuk mata pelajaran IPA di SMP Negeri 5 Baubau adalah 70.

Salah satu cara yang dapat digunakan oleh guru untuk meningkatkan motivasi, aktifitas dan hasil belajar siswa adalah penerapan pembelajaran kooperatif. Pembelajaran kooperatif merupakan salah satu model pembelajaran dengan membentuk siswa belajar dalam kelompokkelompok kecil (Slavin 2009). Pembelajaran kooperatif menciptakan kondisi lingkungan di dalam kelas saling mendukung melalui belajar dengan kelompok kecil dan diskusi kelompok dalam kelas. Aktivitas pembelajaran kooperatif menekankan pada kesadaran siswa berpikir kritis, memecahkan masalah dan belajar bekerja sama dengan anggota lain dalam satu kelompok. Pembelajaran kooperatif yang merangsang keaktifan siswa adalah model pembelajaran Numbered Heads Together (NHT). Model pembelajaran NHT adalah model pembelajaran yang lebih memungkinkan siswa untuk lebih aktif dan bertanggung jawab penuh untuk memahami materi pelajaran baik secara kelompok maupun individual (Kusumojanto 2009).

Pada proses pembelajaran siswa lebih bertanggungjawab terhadap tugas yang diberikan karena dalam pembelajaran kooperatif tipe NHT siswa dalam kelompok diberi nomor yang berbeda. Setiap siswa diwajibkan untuk menyelesaikan soal yang sesuai dengan nomor anggota mereka. Dengan pembelajaran semacam ini siswa dapat melakukan diskusi dengan sungguhsungguh dan juga siswa yang pandai dapat mengajari siswa yang kurang pandai sehingga dapat meminimalkan tingkat kesulitan belajar biologi khususnya pada materi klasifikasi makhluk hidup.

Materi klasifikasi makhluk hidup berisi tentang pengelompokan berbagai macam makhluk hidup. Makhluk hidup dibagi menjadi 5 kingdom, yaitu monera, protista, plantae, fungi, dan animalia. 


\section{SANG PENCERAH}

Volume 3, Nomor 1, Februari 2017, Hlm. 63-73

Wa Ode Hariyana: Penerapan Model Kooperatif Tipe ...

Pengajaran materi ini membutuhkan media yang dapat membantu menjelaskan pengelompokan makhluk hidup. Buklet dapat digunakan dalam pembelajaran. Buklet berisi berbagai macam gambar makhluk yang digunakan dalam pengelompokan makhluk hidup. Penggunaan buklet dapat membuat konsep yang abstrak menjadi lebih konkrit dan lebih mudah dipahami oleh siswa.

Sebagai media dalam pembelajaran, buklet diharapkan akan mempermudah siswa dalam memahami materi dan mengatasi keterbatasan pengamatan. Siswa mudah memahami materi klasifikasi makhluk hidup dengan diskusi kelompok dan dibimbing oleh guru. Berdasarkan uraian di atas, maka fokus dari penelitian ini adalah penerapan pembelajaran kooperatif tipe NHT.

Pembelajaran kooperatif yang merangsang keaktifan siswa adalah model pembelajaran Numbered Heads Together (NHT). Model pembelajaran NHT adalah model pembelajaran yang lebih memungkinkan siswa untuk lebih aktif dan bertanggung jawab penuh untuk memahami materi pelajaran baik secara kelompok maupun individual (Kusumojanto 2009). Pada proses pembelajaran siswa lebih bertanggungjawab terhadap tugas yang diberikan karena dalam pembelajaran kooperatif tipe NHT siswa dalam kelompok diberi nomor yang berbeda. Setiap siswa diwajibkan untuk menyelesaikan soal yang sesuai dengan nomor anggota mereka. Dengan pembelajaran semacam ini siswa dapat melakukan diskusi dengan sungguhsungguh dan juga siswa yang pandai dapat mengajari siswa yang kurang pandai sehingga dapat meminimalkan tingkat kesulitan belajar biologi khususnya pada materi klasifikasi makhluk hidup.

Materi klasifikasi makhluk hidup berisi tentang pengelompokan berbagai macam makhluk hidup. Makhluk hidup dibagi menjadi 5 kingdom, yaitu monera, protista, plantae, fungi, dan animalia. Pengajaran materi ini membutuhkan media yang dapat membantu menjelaskan pengelompokan makhluk hidup. Buklet dapat digunakan dalam pembelajaran. Buklet berisi berbagai macam gambar makhluk yang digunakan dalam pengelompokkan makhluk hidup. Penggunaan buklet dapat membuat konsep yang abstrak menjadi lebih konkrit dan lebih mudah dipahami oleh siswa.

Sebagai media dalam pembelajaran, buklet diharapkan akan mempermudah siswa dalam memahami materi dan mengatasi keterbatasan pengamatan. Siswa mudah memahami materi klasifikasi makhluk hidup dengan diskusi kelompok dan dibimbing oleh guru. Berdasarkan uraian di atas, maka fokus dari penelitian ini bagaimana penerapan pembelajaran kooperatif tipe NHT menggunakan media buklet pada materi klasifikasi makhluk hidup?

Tujuan penelitian ini adalah untuk mengetahui efektivitas penerapan pembelajaran kooperatif tipe NHT menggunakan media buklet pada materi klasifikasi makhluk hidup.

\section{Metode Penelitian}

\section{Lokasi dan Waktu Penelitian}

Penelitian ini dilaksanakan di SMP Negeri 5 Baubau Kelas VII pada Semester Gasal Tahun Ajaran 2012/2013.

\section{Populasi dan Sampel}

Populasi penelitian ini adalah siswa kelas VII semester gasal sebanyak enam kelas, yaitu kelas VII-1, VII-2, VII-3, VII-4, dan VII-5. Sampel dalam penelitian ini adalah dua kelas dari lima kelas yang ada. Prosedur pengambilan sampel pada penelitian ini menggunakan teknik cluster random sampling (pengundian secara acak). 


\section{SANG PENCERAH}

Volume 3, Nomor 1, Februari 2017, Hlm. 63-73

Wa Ode Hariyana: Penerapan Model Kooperatif Tipe ...

\section{Variabel Penelitian}

Variabel dalam penelitian ini, yaitu variabel bebas model pembelajaran kooperatif tipe NHT menggunakan media buklet dan Variabel terikat hasil belajar Biologi siswa dan aktivitas siswa selama proses pembelajaran.

\section{Rancangan Penelitian}

Desain penelitian yang akan digunakan dalam penelitian ini adalah true experimental design yang dirancang dengan metode Pretest Posttest Control Group Design. Dalam desain ini terdapat dua kelompok yang dipilih secara random, kemudian diberi pretest untuk mengetahui keadaan awal adakah perbedaan antara kelompok eksperimen dan kelompok kontrol. Hasil pretest yang baik bila nilai kelompok eksperimen tidak berbeda signifikan.

\section{Sumber Data}

Sumber data dalam penelitian ini adalah siswa. Jenis data yang diperoleh berupa (1) Hasil belajar siswa; (2) Aktivitas siswa dalam proses pembelajaran; dan (3) Tanggapan siswa terhadap proses pembelajaran.

\section{Metode Pengumpulan Data}

Cara pengambilan data, sebagai berikut (1) Hasil belajar siswa diperoleh dari nilai pre test dan post test; (2) Aktivitas siswa dalam proses pembelajaran diambil dengan menggunakan lembar observasi aktivitas siswa; dan (3) Data tanggapan siswa mengenai proses pembelajaran diambil dengan menggunakan angket.

\section{Pembahasan}

Penelitian ini dilaksanakan pada bulan Oktober Tahun Ajaran 2012/2013 yang dilaksanakan di SMP Negeri 5 Baubau. Sampel dalam penelitian ini yaitu Kelas VII4 sebagai kelas kontrol dan VII-2 sebagai kelas eksperimen. Hasil penelitian meliputi aktivitas siswa, hasil belajar siswa, tanggapan siswa terhadap proses pembelajaran.

Aktivitas siswa diperoleh dari hasil pengamatan yang dilakukan oleh observer selama pembelajaran berlangsung. Data aktivitas siswa digunakan untuk mengetahui sejauh mana aktivitas siswa dalam mengikuti proses pembelajaran. Rekapitulasi hasil observasi aktivitas siswa pada masingmasing kelas disajikan pada tabel berikut.

\section{Tabel 1 Aktivitas Siswa Selama Pembelajaran}

\begin{tabular}{|c|c|c|c|c|c|c|c|}
\hline \multirow{2}{*}{ No } & \multirow{2}{*}{ Kriteria } & \multicolumn{2}{|c|}{ Eksperimen } & \multirow{2}{*}{$\begin{array}{l}\text { Rata- } \\
\text { Rata }\end{array}$} & \multicolumn{2}{|c|}{ Kontrol } & \multirow{2}{*}{$\begin{array}{c}\text { Rerat } \\
\text { a }\end{array}$} \\
\hline & & 1 & 2 & & 1 & 2 & \\
\hline 1. & SA & $20(63 \%)$ & $24(75 \%)$ & $69,0 \%$ & $8(25 \%)$ & $9(28 \%)$ & $26,5 \%$ \\
\hline 2. & A & $9(28 \%)$ & $8(25 \%)$ & $26,5 \%$ & $13(41 \%)$ & $14(44 \%)$ & $42,5 \%$ \\
\hline 3. & $\mathrm{CA}$ & $3(9 \%)$ & $0(0 \%)$ & $4,5 \%$ & $9(28 \%)$ & $7(22 \%)$ & $25,0 \%$ \\
\hline 4. & KA & $0(0 \%)$ & $0(0 \%)$ & $0,0 \%$ & $1(3 \%)$ & $2(6 \%)$ & $4,5 \%$ \\
\hline 5. & TA & $0(0 \%)$ & $0(0 \%)$ & $0,0 \%$ & $1(3 \%)$ & $0(0 \%)$ & $1,5 \%$ \\
\hline \multicolumn{2}{|c|}{ Aktif } & $29(91 \%)$ & $32(100 \%)$ & $95,5 \%$ & $21(66 \%)$ & $23(72 \%)$ & $69,0 \%$ \\
\hline \multicolumn{2}{|c|}{ Tidak Aktif } & $3(9 \%)$ & $0(0 \%)$ & $4,5 \%$ & $11(34 \%)$ & $9(28 \%)$ & $31,0 \%$ \\
\hline
\end{tabular}

Keterangan:

Jumlah aktif (aktif + sangat aktif), jumlah tidak aktif (cukup + kurang + tidak aktif)

Tabel menunjukan peningkatan aktivitas siswa pada kelas eksperimen dan kontrol mulai pertemuan pertama sampai pertemuan selanjutnya. Keaktifan siswa pada kelas eksperimen lebih tinggi dibandingkan dengan kelas kontrol mendekati 1,5 kalinya. Persentase siswa tidak aktif pada kelas kontrol hampir 7 kali dari persentase siswa tidak aktif pada kelas ekperimen. Pada kelas kontrol terjadi penurunan persentase kriteria siswa tidak aktif.

Hasil belajar siswa digunakan untuk mengetahui tingkat pemahaman siswa terhadap materi. Hasil belajar siswa tahap awal diperoleh berdasarkan nilai pretest. Nilai pretest digunakan untuk mengetahui kondisi awal kelas eksperimen dan kelas kontrol, yaitu menggunakan uji normalitas dan kesamaan dua varians pada Tabel. 


\section{SANG PENCERAH}

Volume 3, Nomor 1, Februari 2017, Hlm. 63-73

Wa Ode Hariyana: Penerapan Model Kooperatif Tipe ...

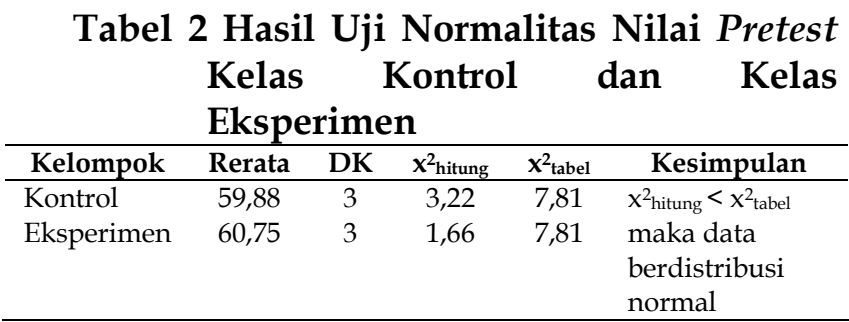

Tabel di atas menunjukkan hasil belajar kelas kontrol dan kelas eksperimen berdistribusi normal. Data yang berdistribusi normal berarti mempunyai sebaran yang normal pula, maksudnya pembagian siswa ke dalam kelas sudah secara merata. Setiap kelas terdapat siswa yang pandai, kemampuan sedang dan siswa yang kemampuannya kurang.

Tabel 3 Hasil Uji Keasamaan Dua Varians Nilai pre test Kelas Kontrol dan Kelas Eksperimen

\begin{tabular}{|c|c|c|c|c|}
\hline Kelompok & $\begin{array}{l}\text { Rata- } \\
\text { Rata }\end{array}$ & $F_{\text {hitung }}$ & $F_{\text {tabel }}$ & Kesimpulan \\
\hline Kontrol & 59,88 & 121 & 182 & $\mathbf{F}_{\text {hitung }}<\mathrm{F}_{\text {tabel }}$ maka \\
\hline Eksperimen & 60,75 & & & $\begin{array}{l}\text { kelas eksperimen } \\
\text { memiliki varians } \\
\text { yang sama }\end{array}$ \\
\hline
\end{tabular}

Tabel menunjukan bahwa kelas eksperimen dan kelas kontrol memiliki varians yang sama (homogen). Kemampuan setiap siswa sama rata tidak ada perbedaan yang mencolok. Perbedaan hasil belajar siswa kelas NHT menggunakan media buklet dan hasil belajar siswa kelas kontrol dianalisis menggunakan uji perbedaan dua rerata (uji-t) (Tabel).

Tabel 4 Hasil Uji T Nilai Pre Test dan Post Test Siswa Kelas Kontrol dan Kelas Eksperimen

\begin{tabular}{lccccc}
\hline \multicolumn{1}{c}{ Kelompok } & Rerata & DK & $\mathbf{t}_{\text {tabel }}$ & $\boldsymbol{t}_{\text {hitung }}$ & Kesimpulan \\
\hline Kontrol & 67,13 & \multirow{2}{*}{62,00} & 1,67 & \multirow{2}{*}{3,51} & Ha diterima \\
Eksperimen & 74,63 & & & & \\
\hline
\end{tabular}

Hipotesis alternatif (Ha) diterima, ditunjukkan dengan data $\mathrm{t}$ hitung $>\mathrm{t}$ tabel. Tabel menunjukkan adanya perbedaan hasil belajar yang signifikan antara kelas ekperimen dengan kelas kontrol. Selain itu, untuk mengukur peningkatan hasil belajar siswa menggunakan normalitas gain (Ngain). Hasil pengukuran N-gain pada kelas eksperimen dan kelas kontrol ditunjukkan pada Tabel.

Tabel 5 Hasil Perhitungan Normal Gain Kelas Eksperimen dan Kelas Kontrol

\begin{tabular}{|c|c|c|c|c|c|c|}
\hline \multirow{2}{*}{ Data } & \multicolumn{2}{|c|}{ Eksperimen } & \multirow{2}{*}{$\begin{array}{l}\mathrm{N}- \\
\text { gain }\end{array}$} & \multicolumn{2}{|c|}{ Kontrol } & \multirow{2}{*}{$\begin{array}{l}\mathrm{N}- \\
\text { gain }\end{array}$} \\
\hline & Pretest & Posttest & & Pretest & Posttest & \\
\hline Nilai tertinggi & 72,00 & 92,00 & & 76,00 & 76,00 & \\
\hline Nilai terendah & 48,00 & 56,00 & 0,35 & 48,00 & 48,00 & 0,18 \\
\hline Rata-rata & 60,75 & 74,63 & & 59,88 & 67,13 & \\
\hline
\end{tabular}

Nilai N-gain kelas eksperimen termasuk kategori sedang $(0,35)$, sedangkan pada kelas kontrol termasuk kategori rendah $(0,18)$. Peningkatan hasil belajar siswa kelas eksperimen lebih tinggi daripada kelas kontrol.

\section{Tanggapan Siswa}

Siswa memberikan tanggapan terhadap pembelajaran yang diterapkan pada lembar angket. Angket yang berisi 10 butir pertanyaan tentang pembelajaran diisi oleh siswa setelah pembelajaran pada pertemuan terakhir. Analisis tanggapan siswa dilakukan untuk mengetahui respon siswa terhadap pembelajaran materi klasifikasi makhluk hidup dengan model NHT menggunakan media buklet.

Sebagian besar siswa (85\%) memberi tanggapan sangat baik terhadap pembelajaran model NHT menggunakan media buklet. Angka 100\% pada butir angket menunjukkan siswa kelas VII.2 tertarik dan termotivasi mengikuti pembelajaran materi klasifikasi makhluk hidup dengan model NHT berbantu media buklet. Siswa merasa pembelajaran dengan model ini memudahkan memahami materi klasifikasi makhluk hidup. Persentase pada 


\section{SANG PENCERAH}

Volume 3, Nomor 1, Februari 2017, Hlm. 63-73

Wa Ode Hariyana: Penerapan Model Kooperatif Tipe ...

butir ke 4, 5, dan 9 di bawah 90\%, berarti ada beberapa siswa yang belum dapat mengikuti pembelajaran dengan baik.

Tabel 6 Hasil Tanggapan Siswa terhadap Pembelajaran Klasifikasi Makhluk Hidup dengan Model NHT Menggunakan Media Buklet

\begin{tabular}{|c|c|c|}
\hline \multirow{2}{*}{ Butir Angket } & \multicolumn{2}{|c|}{$\begin{array}{c}\text { Kelas } \\
\text { Eksperimen }\end{array}$} \\
\hline & Skor & $\begin{array}{c}\text { Presentase } \\
(\%)\end{array}$ \\
\hline $\begin{array}{l}\text { Saya merasa tertarik mengikuti } \\
\text { pembelajaran materi } \\
\text { makhluk hidup dengan modal NHT } \\
\text { berbantu media buklet }\end{array}$ & 32 & $100 \%$ \\
\hline $\begin{array}{l}\text { Pembelajaran yang dilakukan } \\
\text { membuat saya lebih mudah } \\
\text { memahami materi }\end{array}$ & 32 & $100 \%$ \\
\hline $\begin{array}{l}\text { Dengan pembelajaran seperti ini } \\
\text { dapat meningkatkan kerjasama } \\
\text { dalam pembelajaran kelompok }\end{array}$ & 30 & $94 \%$ \\
\hline $\begin{array}{l}\text { Pembelajaran yang dilakukan } \\
\text { membuat saya senang }\end{array}$ & 27 & $84 \%$ \\
\hline $\begin{array}{l}\text { Pembelajaran yang dilakukan } \\
\text { membuat saya aktif }\end{array}$ & 28 & $99 \%$ \\
\hline $\begin{array}{l}\text { Saya kesulitan melaksanakan } \\
\text { pembelajaran yang ada }\end{array}$ & 0 & $0 \%$ \\
\hline $\begin{array}{l}\text { Media buklet yang digunakan dalam } \\
\text { pembelajaran menarik untuk dibaca }\end{array}$ & 32 & $100 \%$ \\
\hline $\begin{array}{l}\text { Media buklet yang digunakan dalam } \\
\text { pembelajaran materi klasifikasi } \\
\text { makhluk hidup membantu saya } \\
\text { memahami materi }\end{array}$ & 30 & $94 \%$ \\
\hline $\begin{array}{l}\text { Istilah-istilah biologi yang terdapat } \\
\text { dalam buklet mudah dipahami }\end{array}$ & 28 & $88 \%$ \\
\hline $\begin{array}{l}\text { Pembelajaran materi klasifikasi } \\
\text { makhluk hidup dengan model NHT } \\
\text { berbantu media buklet membuat } \\
\text { saya lebih termotivasi dalam belajar } \\
\text { Biologi }\end{array}$ & 27 & $85 \%$ \\
\hline
\end{tabular}

\section{Pembahasan}

NHT dalam pembelajaran fisika. Model kooperatif NHT merupakan strategi pembelajaran yang mengutamakan adanya kerjasama antar siswa dalam kelompok untuk mencapai tujuan pembelajaran. Para siswa dibagi ke dalam kelompok- kelompok kecil dan diarahkan untuk mempelajari materi pelajaran yang telah ditentukan. Tujuan dibentuknya kelompok adalah untuk memberikan kesempatan kepada siswa agar dapat terlibat secara aktif dalam proses berpikir dalam kegiatan-kegiatan belajar. Dalam kegiatan diskusi, siswa diberi kebebasan bertanya dan berdiskusi yang mendukung kerja kelompok sehingga siswa merasa senang dan termotivasi untuk mengikuti pembelajaran. Kegiatan diskusi memudahkan siswa memahami dan mengingat kembali apa yang telah dipelajari karena pengetahuan dibangun oleh siswa sendiri baik secara personal maupun sosial. Pengetahuan tidak dapat dipindahkan dengan begitu saja dari pemahaman seorang guru ke pemahaman siswanya. Setiap siswa harus membangun pengetahuan itu di dalam pemahaman masing-masing. (Purnomo 2011).

Menurut Haydon, et al (2010) pembelajaran kooperatif model NHT lebih efektif dibandingkan dengan model pembelajaran konvensional. Model NHT terbukti mampu meningkatkan hasil belajar kelas eksperimen karena model NHT memberikan tanggung jawab individu untuk dapat menyelesaikan permasalahan yang diberikan. Tanggung jawab yang diberikan pada setiap individu membuat siswa menjadi termotivasi dalam pembelajaran. Setiap siswa wajib mengerti dan memahami jawaban/solusi yang telah ditemukan. Agar siswa dapat memahami semua jawaban maka siswa saling bertukar pikiran, berdiskusi dan bertukar pendapat dalam memecahkan soal dalam LDS. Kelompok yang heterogen memberikan kemudahan siswa dalam berdiskusi.

Siswa dengan kemampuan tinggi akan memberikan bantuannnya kepada siswa yang berkemampuan di bawahnya, dengan kegiatan tersebut tentunya pemahaman materi yang dipelajari siswa berkemampuan tinggi akan lebih mendalam, sedangkan siswa dengan kemampuan sedang dan rendah akan semakin mengerti dan paham dengan penjelasan dari temannya. Tidak hanya sekadar memberitahukan jawaban LDS kepada 


\section{SANG PENCERAH}

Volume 3, Nomor 1, Februari 2017, Hlm. 63-73

Wa Ode Hariyana: Penerapan Model Kooperatif Tipe ...

temannya tetapi menjelaskan sampai anggota kelompoknya itu benar- benar memahami jawaban dari LDS. Semua anggota kelompok wajib memahami jawaban yang ditemukan karena guru akan memanggil nomor kepala siswa yang mewakili kelompoknya tanpa memberitahu terlebih dahulu siapa yang akan mewakili kelompoknya tersebut.

Kelas kontrol melakukan diskusi tanpa menggunakan model NHT. Pada saat diskusi, siswa yang aktif berdiskusi hanya 23 anggota saja. Anggota yang lain tidak berkontribusi dalam diskusi dan mengandalkan teman kelompoknya untuk menyelesaikan permasalahan yang diberikan. Hal ini terjadi karena didalam kelompok diskusi konvensional tidak memberikan tanggung jawab individu kepada setiap anggota, sehingga ada anggota yang berpikiran bahwa tugas kelompoknya akan diselesaikan oleh temannya yang lebih pandai. Pada saat posttest hanya siswa yang aktif berdiskusi saja yang mudah mengerjakan soal yang diberikan. Menurut Slavin (2009) pada kelas eksperimen yang masing- masing anggotanya aktif dalam diskusi dapat dengan mudah mengerjakan pos test yang diberikan. Dalam kelompok yang tidak memasukkan tanggung jawab individu, satu atau dua orang anggota kelompok mungkin akan mengerjakan tugas kelompoknya, sedangkan yang lainnya tidak berkontribusi dalam kegiatan kelompok.

Secara umum, penerapan kooperatif tipe NHT menggunakan media buklet dapat dinyatakan sangat baik diterapkan dalam materi klasifikasi makhluk hidup karena dari hasil analisis data didapatkan hasil belajar dengan peningkatan yang signifikan pada masing-masing siswa. Namun ada beberapa siswa yang pencapaian hasil belajarnya dibawah KKM yang telah ditetapkan yaitu 70. Hal ini dapat terjadi karena setiap siswa memiliki tingkat pemahaman dan kemampuan yang berbeda- beda. Menurut Rifa'i dan Anni (2009) hasil belajar siswa dipengaruhi oleh kondisi internal dan kondisi eksternal siswa. Kondisi internal siswa mencakup kondisi fisik seperti kesehatan siswa, kondisi psikis seperti kemampuan intelektual, emosional, dan kondisi sosial. Faktor eksternal seperti variasi dan tingkat kesulitan materi belajar yang dipelajari, tempat belajar, iklim dan suasana lingkungan. Kelas eksperimen diketahui sebanyak 29 siswa telah mencapai KKM yang telah ditetapkan, sedangkan 3 siswa tidak mencapai KKM.

Hasil penelitian menunjukkan bahwa kelas kontrol mempunyai rerata nilai kelas 74,13 dengan siswa yang telah memenuhi KKM individu $\geq 70$ yaitu 24 siswa dan 8 siswa tidak memenuhi KKM. Ketuntasan belajar kelas kontrol yang diperoleh sebesar $75 \%$ tidak mencapai target yang diharapkan yakni $\geq 85 \%$ siswa tuntas dalam pembelajaran biologi. Rerata nilai hasil belajar untuk kelas eksperimen sebesar 80,58 dengan siswa yang telah memenuhi KKM individu $\geq 70$ sebanyak 29 siswa dan 3 siswa tidak memenuhi KKM. Ketuntasan belajar kelas eksperimen diperoleh sebesar 91\%, maka kelas ini telah mencapai KKM Biologi yang ditetapkan yakni $\geq 85 \%$ siswa tuntas.

Penggunaan model kooperatif NHT pada materi klasifikasi makhluk hidup sudah tepat. Isi materi klasifikasi makhluk hidup sangat luas karena menjelaskan pengelompokan berbagai macam makhluk hidup. Tanpa menggunakan metode yang tepat dalam pembelajaran pastilah siswa akan mengalami kesulitan dalam pembelajaran. Adanya pembagian tugas dalam kelompok NHT membuat setiap siswa lebih mudah memahami materi dan siswa lebih bertanggung jawab kepada tugasnya. Model NHT menekankan kerja sama kelompok, tidak ada anggota yang tidak berkontribusi dalam kegiatan diskusi. Selain model NHT yang digunakan, media buklet juga sangat berperan dalam peningkatan hasil belajar siswa. Buklet berisi 


\section{SANG PENCERAH}

Volume 3, Nomor 1, Februari 2017, Hlm. 63-73

Wa Ode Hariyana: Penerapan Model Kooperatif Tipe ...

gambar-gambar contoh makhluk hidup. Media buklet membantu memvisualisasikan pemahaman siswa yang abstrak menjadi lebih nyata dengan bantuan gambar-gambar yang ada di buklet. Media buklet memudahkan pemahaman siswa terhadap materi klasifikasi makhluk hidup. Sebuah gambar dapat berfungsi untuk menarik dan mengarahkan perhatian siswa terhadap bahan pembelajaran yang disajikan (Iriaji 2009).

Kelebihan tipe NHT adalah melatih siswa meningkatkan keterampilan berkomunikasi melalui diskusi kelompok, memberikan waktu lebih banyak untuk berpikir, menjawab, dan saling membantu satu sama lain, dan meningkatkan berpikir siswa baik secara individu maupun kelompok. Selama diskusi kelompok secara tidak langsung dapat mengoptimalkan pendidikan kecakapan hidup khususnya kecakapan sosial dan kecakapan berfikir rasional siswa. Kecakapan sosial dapat dicapai dengan bekerja sama antar teman dalam kelompok untuk menyelesaikan masalah, mengembangkan kecakapan dalam berkomunikasi baik lisan maupun tulisan. Kecakapan berfikir rasional dapat dilihat dari bagaimana cara siswa dalam memahami dan menyelesaikan soal klasifikasi makhluk hidup.

Aktivitas siswa sangat penting agar hasil belajar yang diperoleh siswa optimal, karena aktivitas siswa sangat menentukan hasil belajar siswa. Aktivitas siswa ditunjukkan dengan berbagai tindakan atau kegiatan yang mendukung proses pembelajaran, seperti memperhatikan penjelasan materi pembelajaran, berbicara yang relevan dengan materi pembelajaran dan mengerjakan tugas sesuai dengan materi yang diberikan. Aktivitas belajar siswa menentukan hasil belajarnya. Siswa-siswa yang memiliki aktivitas belajar tinggi selama proses pembelajaran, memperoleh hasil belajar yang lebih baik, dan sebaliknya siswa yang memiliki aktivitas belajar rendah, memperoleh hasil belajar yang rendah pula (Khotimah dan Mukhafifah 2011). Aktivitas sangat berpengaruh terhadap peningkatan hasil belajar. Hal tersebut sesuai dengan hasil penelitian ini, yaitu pada kelas eksperimen 95\% siswa aktif dalam pembelajaran dan siswa yang tuntas belajar mencapai 91\% sedangkan pada kelas kontrol $69 \%$ siswa aktif dalam pembelajaran dan siswa yang tuntas belajar mencapai $75 \%$.

Hasil observasi yang telah dilakukan menunjukkan bahwa kelas eksperimen memiliki kategori tingkat aktivitas yang lebih tinggi bila dibandingkan kelas kontrol. Besarnya antusias siswa dalam pembelajaran ditunjukkan dengan keaktifan siswa saat proses belajar mengajar. Hasil analisis aktivitas siswa kelas eksperimen menunjukkan bahwa kategori aktivitas siswa sebanyak $69 \%$ sangat aktif, $26,5 \%$ aktif, $4,5 \%$ cukup aktif, $0 \%$ pada kriteria kurang dan tidak aktif. Aktivitas siswa kelas kontrol yang tergolong dalam kategori sangat aktif sebesar $26,5 \%$, aktif $42,5 \%$, cukup aktif $25 \%$, kurang aktif $4,5 \%$ dan tidak aktif $1,5 \%$. Pada kelas eksperimen didapatkan hasil 4,5\% pada kriteria cukup aktif. Hal ini menunjukkan bahwa masih ada kekurangan dalam kegiatan pembelajaran. Banyak faktor yang dapat menjadi penyebabnya, yaitu sewaktu diskusi ada siswa yang malu bertanya kepada guru, siswa belum terbiasa dengan pembelajaran NHT, siswa kurang termotivasi dengan pembelajaran dan kondisi siswa yang tidak sehat. Kondisi atau suasana belajar kelas mempengaruhi tingkat motivasi siswa (Silalahi 2008).

Aktivitas siswa selama proses belajar mengajar merupakan salah satu indikator adanya keinginan siswa untuk belajar. Aktivitas siswa merupakan kegiatan atau perilaku yang terjadi selama proses belajar mengajar. Siswa dikatakan memiliki keaktifan apabila ditemukan ciri-ciri perilaku seperti sering bertanya kepada guru atau siswa lain, mau mengerjakan tugas yang diberikan oleh guru, mampu 


\section{SANG PENCERAH}

Volume 3, Nomor 1, Februari 2017, Hlm. 63-73

Wa Ode Hariyana: Penerapan Model Kooperatif Tipe ...

menjawab pertanyaan, dan senang diberi tugas belajar. Siswa yang memiliki aktivitas dalam kategori aktif dan sangat aktif pada kelas eksperimen lebih banyak jumlahnya bila dibandingkan dengan kelas kontrol. Hal ini menunjukkan bahwa siswa kelas eksperimen memiliki motivasi lebih besar bila dibandingkan dengan kelas kontrol. Motivasi yang besar ini diperoleh dari penerapan pembelajaran kooperatif NHT yang memberikan tanggung jawab kepada setiap siswa agar dapat menyelesaikan LDS yang diberikan. Selain model NHT buklet juga berperan dalam menarik minat dan motivasi siswa. Gambargambar yang terdapat dalam buklet sangat menarik keingintahuan siswa dalam mempelajari materi keanekaragaman makhluk hidup. Menurut Tang (2008) bahwa penggunaan media gambar dapat menimbulkan minat dan motivasi siswa, sehingga siswa lebih aktif dalam pembelajaran.

Pembelajaran kooperatif juga memberikan manfaat positif bagi siswa dalam meningkatkan rasa harga diri dan penerimaan diri siswa. Kerja dalam kelompok juga dapat maksimal sehingga terbentuk saling ketergantungan yang positif antara siswa dalam satu kelompok. Saling ketergantungan tersebut berupa saling ketergantungan pencapaian tujuan, saling ketergantungan menyelesaikan tugas dan saling ketergantungan peran masing-masing siswa dalam kelompok. Dengan adanya ketergantungan tersebut, siswa akan saling membantu dan saling memberikan motivasi.

Berdasarkan hasil analisis tanggapan siswa terhadap pembelajaran model kooperatif tipe NHT menggunakan media buklet dapat diketahui bahwa siswa memberi tanggapan yang positif terhadap pembelajaran yang diterapkan. Hasil analisis data tanggapan siswa diketahui bahwa $85 \%$ siswa memberi tanggapan yang baik terhadap pembelajaran. Hal ini diperkuat dengan hasil analisis tanggapan siswa pada setiap aspeknya. Sebanyak $100 \%$ siswa merasa tertarik dengan pembelajaran kooperatif tipe NHT menggunakan media buklet. Para siswa tertarik dengan pembelajaran ini karena mereka belum pernah belajar menggunakan model NHT, guru hanya mengajar dengan model ceramah diselingi kegiatan diskusi interaktif. Metode ceramah dirasakan kurang efektif dalam memotivasi belajar siswa dan metode ini bersifat konvensional, sehingga cenderung guru yang lebih aktif belajar dibandingkan para siswa (Siswanto dan Rechana 2011).

Sebanyak $100 \%$ siswa merasa pembelajaran kooperatif tipe NHT mempermudah dalam mempelajari materi klasifikasi makhluk hidup. Alasannya karena siswa dapat mendiskusikan materi bersama temannya dalam satu kelompok sehingga lebih mudah memahami materi, dapat saling membantu, dapat berbagi pengetahuan dengan yang lain, dapat bertukar pendapat, dan pembelajaran lebih menyenangkan. Menurut Kailani (2010) pembelajaran kooperatif memberikan peluang kepada anak didik untuk mengembangkan keterampilan sosial, keterampilan kerja sama, dan kolaborasi serta tanya jawab. Pembelajaran kooperatif mendorong anak didik untuk dapat menerima perbedaan kemampuan temanteman yang lain. Media buklet yang digunakan juga mempermudah gambaran siswa tentang contoh-contoh makhluk hidup yang digolongkan. Contoh gambar di buklet mengubah konsep yang abstrak menjadi lebih konkrit dan lebih mudah dipahami oleh siswa. Hal ini dibuktikan dengan tanggapan siswa sebesar $94 \%$ siswa merasa buklet membantu mereka dalam memahami materi klasifikasi makhluk hidup. Media gambar dapat meningkatkan daya serap siswa terhadap materi pelajaran yang diajarkan, sehingga tujuan pembelajaran dapat tercapai secara maksimal (Tang 2008). 


\section{SANG PENCERAH}

Volume 3, Nomor 1, Februari 2017, Hlm. 63-73

Wa Ode Hariyana: Penerapan Model Kooperatif Tipe ...

\begin{abstract}
Sebanyak $94 \%$ siswa berpendapat bahwa pembelajaran NHT dapat meningkatkan kerjasama antar siswa, karena dalam pembelajaran NHT siswa dibagi menjadi beberapa kelompok kecil yang heterogen. Masing-masing anggota kelompok dituntut untuk dapat menyelesaikan tugas yang diberikan. Siswa yang pandai diharapkan untuk mengajari temannya yang belum paham sehingga tiap anggota kelompok mengetahui dan memahami jawaban dari permasalahan yang diberikan. Menurut Sutariawan et al (2011) pada pembelajaran NHT, guru hanya menunjuk seorang siswa yang mewakili kelompoknya tanpa memberi tahu terlebih dahulu siapa yang akan mewakili kelompoknya tersebut. Cara ini menjamin keterlibatan total semua siswa dan upaya yang sangat baik untuk meningakatkan tanggung jawab individual dalam diskusi kelompok.
\end{abstract}

Penggunaan model-model dalam pembelajaran dapat meningkatkan motivasi belajar siswa. Dengan model yang bervariasi siswa menjadi semangat dan tidak merasa bosan dalam pembelajaran. Siswa juga merasa aktif dan senang dengan suasana pembelajaran dengan model yang berbeda. Hal ini dibuktikan dari tanggapan siswa sebesar $100 \%$ yang menyatakan bahwa pembelajaran model koopertif NHT dengan media buklet membuat siswa termotivasi dalam pembelajaran biologi dan $84 \%$ siswa merasa senang dengan model koopertif tipe NHT dengan media buklet. Model pembelajaran kooperatif dapat meningkatkan interaksi siswa serta dapat meningkatkan motivasi siswa untuk aktif dalam proses pembelajaran (Yusuf dan Natalina 2005).

Tanggapan yang diberikan siswa dapat disimpulkan bahwa pembelajaran yang dilaksanakan membuat siswa merasa tertarik, mudah mempelajari materi, tidak mengalami kesulitan, merasa suasana kelas menyenangkan, siswa lebih aktif, dan mempunyai motivasi yang tinggi untuk belajar. Hal ini menunjukkan bahwa dengan menggunakan model pembelajaran kooperatif tipe NHT dengan media buklet mendapat respon positif dari siswa.

\section{Simpulan}

Simpulan penelitian ini bahwa penerapan model kooperatif tipe NHT menggunakan media buklet dapat mengoptimalkan hasil belajar dan aktivitas siswa pada materi klasifikasi makhluk hidup di SMP Negeri 5 Baubau. Sebanyak 100\% siswa merasa pembelajaran kooperatif tipe NHT mempermudah dalam mempelajari materi klasifikasi makhluk hidup.

\section{Daftar Pustaka}

Anni CT. 2007. Psikologi Belajar. Semarang: Universitas Negeri Semarang Press.

Arikunto S. 2010. Dasar-Dasar Evaluasi Pendidikan. Jakarta: Bumi Aksara.

Daryanto. 2011. Media Pembelajaran. Bandung: Satu Nusa.

Djohani R, Widyanto DJ, \& Irfani R. 2007. Mengembangkan Media Komunikasi Berbasis Masyarakat. Jakarta: Tim Partnerships for e-Prosperity for the Poor (Pe-PP) Bappenas - UNDP

Iriaji. 2009. Pengembangan gambar illustrasi berspektif jender pada buku teks sekolah dasar kelas awal. Jurnal Penelitian Pendidikan 19 (2): 152-164

Khotimah PR \& Mukhafifah. 2011. Eksperimentasi pembelajaran matematika melalui metode Team Quiz 


\section{SANG PENCERAH}

Volume 3, Nomor 1, Februari 2017, Hlm. 63-73

Wa Ode Hariyana: Penerapan Model Kooperatif Tipe ...

dan Learning Cell ditinjau dari aktivitas belajar siswa. Semanas : 1-5

Lago RGM. 2007. Influence of Cooperative Learning on chemistry students' achievement, self-efficacy and attitude. Liceo Journal of Higher Education Research 5 (1): 1-9.

Mustafa, Yusnani, \& Baharuddin. 2011. Penerapan pembelajaran kooperatif model numbered heads together (NHT) untuk meningkatkan keaktifan dan penguasaan konsep matematika. Jurnal PTK DBE3 Khusus (1): 7-14.

Purnomo YW. 2011. Keefektifan model penemuan terbimbing dan Cooperative Learning pada pembelajaran matematika. Jurnal Pendidikan 41 (1): 37-54

Rifa'i A \& Anni CT. 2009. Psikologi Pendidikan. Semarang: Universitas Negeri Semarang Press.

Saptono S. 2009. Strategi Belajar Mengajar Biologi. Semarang: Universitas Negeri Semarang

Silalahi J. 2008. Pengaruh iklim kelas terhadap motivasi belajar. Jurnal Pembelajaran 30 (2) : 100-105.

Slavin RE. 2009. Cooperative Learning Teori, Riset, dan Praktik. Bandung: Nusa Media.

Sugandi A. 2007. Teori Pembelajaran. Semarang: Universitas Negeri Semarang Press.

Sugiyono. 2011. Metode Penelitian Pendidikan (Pendekatan Kuantitatif, Kualitatif, dan RED). Bandung: Alfabeta.

2011. Statistika untuk Penelitian. Bandung: Alfabeta.
Sukestiyarno. 2011. Statistika Dasar. Semarang: Universitas Negeri Semarang Press.

Trianto. 2009. Mendesain Model Pembelajaran Inovatif Progresif. Jakarta: Kencana Prenada Media Group 